\title{
Misconduct row fuels calls for reform
}

Carina Dennis, Sydney

A fierce row over misconduct allegations has prompted Australian researchers to call for an office of research integrity to be set up.

The issue came to a head on 10 February, when Senator Kim Carr, research spokesman for the opposition Labor Party, released to parliament an unpublished report of an inquiry into allegations made about an immunologist at the University of $\mathrm{New}$ South Wales.

The case centres on Bruce Hall, a transplant immunologist working on graft tolerance. In 2001, Hall was accused by four complainants in his laboratory of fabricating and falsifying experimental results in an abstract and paper, providing false data in a grant application, misattributing author-

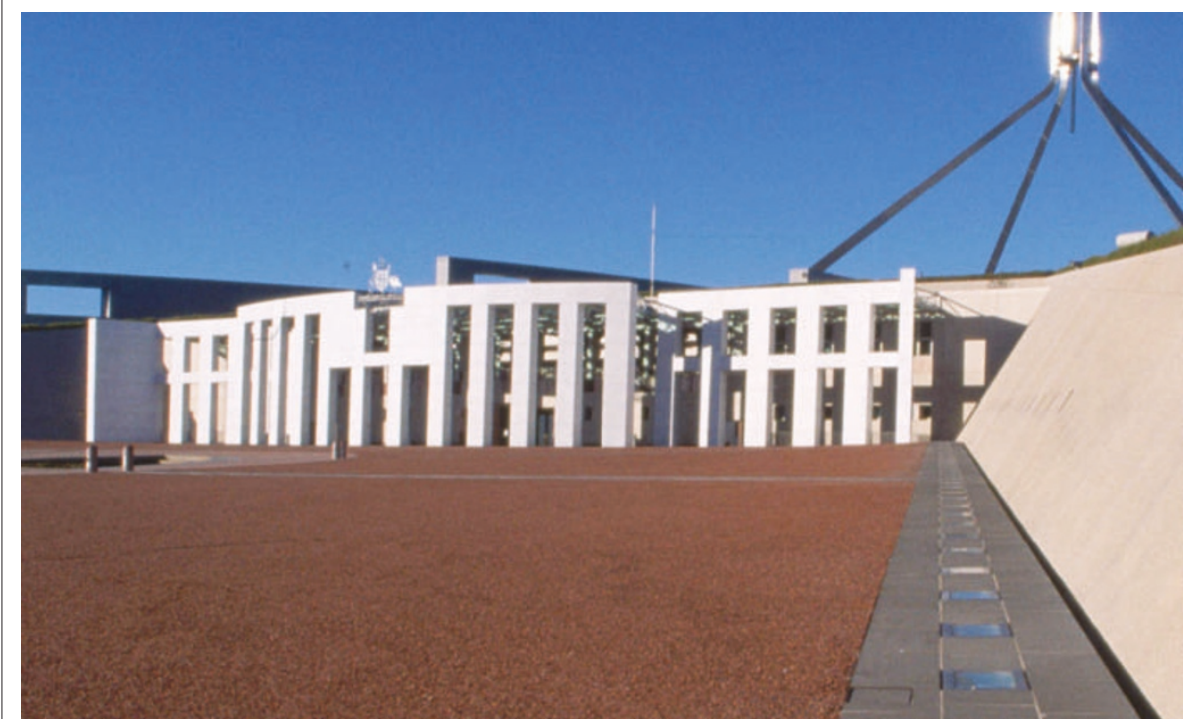

Question time: scientific misconduct has been brought to the fore in Australia's parliament. ship credit and workplace bullying. The experiments in question involved the use of cells from the immune system - called $\mathrm{CD} 4{ }^{+} \mathrm{T}$ cells - to transfer graft tolerance to rats with transplanted hearts. Hall emphatically denies the allegations.

In June 2002, the university commissioned an external panel chaired by Gerard Brennan, Australia's former chief justice, to investigate. The panel's report, delivered to the university in January 2003 but not published until Carr released it, said that Hall had engaged in scientific misconduct.

Hall himself hotly contests the findings of the Brennan report. "They got the science wrong," he says, adding that panel members did not understand his field of research. Before the report's release in parliament,

Hall had taken court action to try to block its publication. And last December, Rory Hume, vice-chancellor of the university, ruled that Hall was not guilty of scientific misconduct and decided to censure him formally for lesser charges of academic misconduct.

But Carr has criticized the university for not releasing the report earlier. "It's a matter a of public interest," says Carr. "I don't believe the university has responded appropriately." Several members of the university's governing council, as well as some faculty members, have also taken issue with the handling of the matter.

For many researchers, the greatest concern is not so much the individual case but the flaws it exposes in the way Australian universities handle misconduct cases. Several have called for an office of research integrity, similar to the one in the US health department. "The current process is inadequate," says Warwick Anderson, head of Monash University's school of biomedical sciences. "We've now been faced with a major case of a reputable investigator and a highly respected university - it has been deeply problematic and hasn't served anyone's interests." Hume agrees: "Australia could do well to have an office of scientific integrity," he says.

The National Health and Medical Research Council, Australia's main funding agency for biomedical research, terminated Hall's grant last October, saying that he had provided misleading information in his grant application. In June 2002, the agency initiated a review of Australia's guidelines on all aspects of the conduct of research, which is being conducted jointly with the Australian Research Council and the universities.

\section{Berlin biologists outraged by imminent pay cut}

\section{Anna Wellmann, Munich}

Biologists at one of Berlin's leading biomedical research centres have been told to prepare for a $12 \%$ pay cut. Unions representing 700 staff at the Max Delbrück Center for Molecular Medicine (MDC) say that they will fight the cut in the courts.

Berlin's government and the federal research ministry, which finance the centre jointly, say that the city's fiscal crisis leaves them no choice but to make the cut. Facing a yawning budget deficit, Berlin decided last August to cut the salaries of its public employees in exchange for a shorter working week and guaranteed jobs until 2009.

The capital's three universities and some other research institutes were exempted, but the MDC was not. The federal research ministry approved the pay cuts at the beginning of this month.

Staff are not amused. They say that, as researchers, they are unlikely to benefit from cuts in their hours. And the guarantee of employment doesn't help, as they are nearly all on five-year, fixed-term contracts.

"I don't know how my family could cope with $12 \%$ less per month," says Thomas Müller, a postdoctoral fellow studying developmental biology at the centre. Udo Heinemann, a crystallographer there, adds that lower salaries will make it hard for the centre to attract staff.

As a compromise, the research ministry has suggested giving MDC employees the same terms as other public workers in eastern Germany. This would result in a $7.5 \%$ pay cut , but no reduction in the working week. Marion Bimmler, who chairs

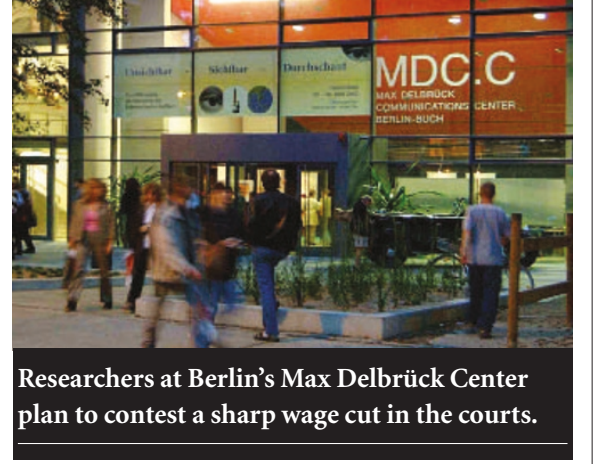

the staff council of the MDC, compares this to "choosing between plague and cholera".

Bimmler says the unions are advised that the pay cut is illegal. But court action could last for more than a year, and the new terms are taking effect immediately. 